\title{
POSSE AGRÁRIA, USUCAPĨ̃o AGRÁRIA E SUAS EXIGÊNCIAS
}

\section{LAND POSSESSION, ADVERSE POSSESSION OF LAND AND ITS REQUIREMENTS}

Milton Inácio Heinen*

\begin{abstract}
Resumo: O presente artigo visa discutir os conceitos de posse, distinguindo posse civil e posse agrária, evidenciando as exigências específicas para a caracterização desta, para abordar, entre as consequências da posse agrária, a aquisição da propriedade pela usucapião, tendo como enfoque central o cumprimento das exigências constitucionais de cumprimento da função social da terra como condição para a aquisição da propriedade e, por via de consequência, a não aplicação do disposto no artigo 1.238 do Código Civil e seu parágrafo único, na aquisição por usucapião de área rural, tendo em vista as maiores exigências relacionadas com o uso adequado da terra, dentro dos ditames fixados pela Constituição Federal. Nestas condições, os dispositivos do Código Civil relacionados com a posse e a aquisição da propriedade pela usucapião, mesmo que posteriores à promulgação da Constituição Federal, não estão em consonância com esta, do que resulta a sua não aplicação na usucapião de área rural.
\end{abstract}

Palavras Chave: Posse agrária, função social da terra, usucapião civil e usucapião agrária.

Abstract: This paper discusses the concept of possession, distinguishing civil and agrarian tenure, showing the specific requirements for the characterization of the agrarian tenure, to approach, among the consequences of land ownership, the acquisition of property by adverse possession, with the central focus in the fulfillment of constitutional requirements for accomplishment of the social function of land, as a condition for the acquisition of property and, in consequence, the inapplicability of Article 1238 of the Civil Code and its sole paragraph, in the acquisition of rural area by acquisitive prescription, having in view of the increased demands related to the appropriate use of land within the dictates set by the Federal Constitution. In those circumstances, the Civil Code provisions relating to the possession and the acquisition of property by adverse possession, even after the enactment of the Federal Constitution, are not in line with it, resulting in his irrelevance in rural acquisitive prescription.

Keywords: land tenure, social function of land, civil and agrarian acquisitive prescription.

\section{Introdução}

A discussão sobre a posse e sua caracterização é antiga. Evidentemente a posse antecede a propriedade. Esta é uma construção jurídica, enquanto que a posse é fato. A posse existe e deve existir e ser reconhecida por si mesma.

No entanto, no decorrer da história, muitas teorias acerca da posse e sua

\footnotetext{
* Milton Inácio Heinen é Mestre em Direito Agrário pela Fac. de Direito da Universidade Federal de Goiás, professor da PUC Goiás e da Fac. Direito da UFG.
} 


\section{MILTON INÁCIO HEINEN}

caracterização foram desenvidas e ainda servem de base para as reflexões atuais e, principalmente, para a atuação e prestação jurisdicional nas situações litigiosas, por parte do judiciário brasileiro.

O que caracteriza o exercício efetivo da posse é objeto de posições doutrinárias divergentes, a depender do enfoque, civilista ou agrarista. Não há dúvida, no entanto, que há distinção clara entre a posse civil e a posse agrária. O exercício da posse de área rural se submete a exigências específicas previstas em lei, independente da condição em que o titular esteja no exercício da posse, seja proprietário ou não, em razão da determinação legal de cumprimento da função social da terra.

No presente trabalho se pretende abordar este assunto, partindo da conceituação da posse, evidenciando os enfoques e exigências distintas entre a legislação civil e agrária e, finalmente, as consequências da posse, entre as quais a aquisição da propriedade pela usucapião, onde se busca demonstrar o não cabimento, em área rural, da usucapião com base apenas nas exigências previstas na Lei $\mathrm{n}^{\circ} 10.406 / 02$, especificamente o disposto nos artigos 1238 e 1243 do referido Código Civil.

\section{Posse}

\subsection{Elementos conceituais e históricos}

A discussão doutrinária acerca da posse remonta ao direito romano, onde diversas teorias se confrontavam, estando presentes nas discussões doutrinárias da idade média, assim como aparece, também, no direito canônico.

No entanto, foi a partir do início do século XIX, que as teorias de Savigny (1803), Ihering (1869) e, pouco mais adiante, Saleilles (1893), passaram a ser o principal referencial das discussões sobre a posse.

Para Savigny, defensor da teoria subjetiva, a posse compõe-se de dois elementos, quais sejam o corpus (o fato do titular ter a coisa consigo; a coisa está fisicamente com alguem que é o possuidor; o fato de dispor fisicamente da coisa) e o animus (a intenção do titular de ter a coisa como sendo o dono ou titular do direito; prática de atos ou comportamento que demonstram esta intenção de ter a coisa como sua, como proprietário). 
Ihering, criticando Savigny, formulou sua teoria objetiva, não admitindo a separação entre corpus e animus, de modo que o fato da posse e a intenção estariam presentes ao mesmo tempo e inseparáveis. Para ele não há proteção à posse pela posse. Esta é mero reflexo da propriedade ou, em outras palavras, a exteriorização da propriedade. Nestas condições o proprietário é naturalmente o possuidor. A posse então é analisada ou verificada apenas em função da propriedade.

Mais tarde, Saleilles formula a sua teoria econômica, segundo a qual a posse é resultado de uma destinação econômica dada à coisa. Desta forma, Saleilles se distancia da formulação dos outros teóricos na medida que desvincula a posse da propriedade, sendo que a posse se vincula a quem deu uma finalidade economica à coisa. Foi um avanço significativo em relação às tradicionais teorias de Savigny e Ihering. ${ }^{12}$

Nosso direito civil (Código Civil de 1916) não definiu a posse. Aliás esta é identificada a partir da figura do possuidor. Alí fica claro que nosso legislador adotou as teorias objetivistas e com identificação da posse como elemento da propriedade, ou seja, a posse somente é vista como elemento integrante do direito de propriedade. No entanto, naquela época e mesmo nos dispositivos do atual código civil, o legislador não adotou a teoria objetiva pura, uma vez que regula a possibilidade de aquisição pela usucapião.

Ocorre que o tempo foi agregando novas concepções ao fenômeno da posse e, sobretudo a partir de outras teses doutrinárias, desvinculando-a da propriedade como única forma de seu reconhecimento, apesar da nossa legislação civil ter evoluido pouco neste sentido.

O fato é que a Constituição Federal de 1988, com seus princípios básicos, passou a estabelecer maiores exigências de uso dos bens, notadamente à terra, considerada como bem de produção de natureza espcial. Porém, esta nova concepção não foi seguida pelas disposições do Código Civil de 2.002, de forma que se constituiu em contradição com as exigências constitucionais no que se refere ao direito de posse e propriedade, especificamente em relação aos imóveis rurais, como veremos. Daí a necessidade de se estabelecerem as distinções entre a posse prevista do Código Civil e aquela a ser identificada em áreas rurais. Trata-se da concepção agrária de posse. 


\section{MILTON INÁCIO HEINEN}

\subsection{Posse Civil e Posse Agrária}

Interessante observar, como já dito, que pouco ou nada evoluimos, em matéria de concepção sobre a posse, entre o Código de 1.916 e o atual Código Civil, de 2.002, uma vez que os artigos 485 e seguintes do primeiro foram reproduzidos, com poucas alterações, nos artigos 1.196 e seguintes do código atual. Contudo, a legislação agrária, tendo como referência maior o comando constitucional, dá novo enfoque à posse e uso da terra, especialmente em se tratando de área rural, de modo que os dispositivos da legislação civil devem ser interpretados e aplicados à luz desta legislação agrária e, sobretudo, das exigências constitucionais.

Como já dito, a posse é situação de fato que, sendo a área rural, se efetiva com o exercício diuturno de atividades agrárias de produção, e também de conservação, com o atendimento aos interesses e necessidades da coletividade, buscando atender às exigências que caracterizam o cumprimento da função social da terra. Substitui-se aqui o termo função social da propriedade por função social da terra, tendo em vista que esta, independente da condição do titular, precisa cumprir a função social.

Os dispositivos do Código Civil relativos à posse estão longe desta configuração, que se denomina de posse agrária.

$\mathrm{O}$ art. 1.196 estabelece que: Considera-se possuidor aquele que tem de fato o exercício, pleno ou não, de algum dos poderes inerentes à propriedade. Quais seriam estes poderes? O artigo 1.228, por sua vez, garante ao proprietário a faculdade de usar, gozar e dispor da coisa, e o direito de reavê-la do poder de quem quer que injustamente a possua ou detenha.

Será que isto é suficiente para o cumprimento das exigências atuais em relação ao uso da terra? É certo que os parágrafos acrescidos ao artigo 1.228, estabelecem limites e exigências no exercício do direito de propriedade mas, ainda assim, estão longe de atender à determinação constitucional em relação à função social da terra.

Cabe observar, em primeiro lugar, que o Código Civil não distingue posse urbana de posse rural, tratando igualmente duas realidades distintas que possuem exigências de uso R. Fac. Dir. UFG, v. 38, n. 2, p. 80 - 96, jul. /dez. 2014 
diferenciadas em função de sua destinação natural e, com outro problema, analisando o direito como sendo interindividual, sem qualquer enfoque social em relação à posse e uso da terra.

Outra questão, sobre a qual a doutrina também é divergente, refere-se à identificação da posse como direito real ou não. A depender do disposto no Código Civil, como se vê na relação fincada no artigo 1.225 , não se trata de direito real, ao passo que a propriedade aparece ali em primeiro lugar. Ocorre que a posse é a situação de fato, de efetivo uso da coisa no interesse do bem comum e, como tal, deveria ser protegida, enquanto posse, como direito real, e mais real do que qualquer outro, data a sua importância, em especial quando se trata de posse de área rural. ${ }^{3}$ A propriredade, por sua vez, é construção jurídica que, como espécie de ficção, se torna real por disposição legal e o centro de todo o direito patrimonialista. Disto resulta a tradição histórica de se proteger mais a propriedade do que a posse e, mais do que isto, a prática de identificar a posse apenas como inerente à propriedade e não por ela mesma.

Assim, o Código Civil vincula a posse à propriedade, como sendo um dos elementos constitutivos desta. É como se não existisse posse sem propriedade e por quem não é proprietário, e muito menos a posse contra a propriedade. Esta é a chamada posse civil, estática, sem maiores exigências em relação ao correto uso da coisa pelo titular. Cabe a utilização desta noção ou regra legal de posse, sendo esta posse incidente sobre área rural?

O Código Civil não define exatamente o que é posse. Como dito acima, refere-se ao possuidor como sendo aquele que tem o exercício de algun dos poderes inerentes à propriedade, cujas consequências ainda precisam ser objeto de análise. Na legislação agrária também não se tem um conceito legal específico sobre a posse agrária, mas o conteúdo mínimo desta pode facilmente ser deduzido dos vários institutos jurídicos e das próprias exigêncioas constitucionais em relação ao adequado uso da terra. As exigências em relação ao cumprimento da função social da terra (denominação de maior alcance) e não apenas da propriedade, são dirigidas igualmente ao possuidor da terra a qualquer título.

Observe que a posse, na definição civil, está vinculada à propriedade, em pouco diferindo da visão histórica e clássica de Savigny, e até mesmo de Ihering, para quem a intenção integra a situação de fato de uso da coisa. A questão se agrava quando o legislador dispõe, no art. 1.228, que o proprietário tem a faculdade de usar, gozar e dispor da coisa. R. Fac. Dir. UFG, v. 38, n. 2, p. 80 - 96, jul. /dez. 2014 


\section{MILTON INÁCIO HEINEN}

Nestas condições, se a posse decorre da propriedade, o possuidor também tem a faculdade de usar a coisa ou de dispor da coisa e, mesmo que não faça efetivo uso desta, ainda assim, teria a posse garantida pela prática de determinados atos, como por exemplo a mera conservação, mesmo que com fins especulativos, resultando dali uma posse decorrente da mera intenção de posssuir. Aliás, ainda é assim que pensam diversos julgadores nos nossos tribunais, sobretudo quando identificam a posse a partir da mera comprovação da titularidade da propriedade, pela juntada de certidão dominial, sem qualquer prova da prática de atos de posse. É como se a posse do proprietário fosse automática e evidente, como intenção, vinculada à propriedade, mesmo sem o cumprimento das exigências constitucionais de uso adequado da terra.

É evidente que a posse existe antes e independente da propriedade, e como tal deve ser protegida, inclusive contra a propriedade, quando seu titular não exerce efetivamente a posse nos termos das exigências constitucionais.

A propriedade é construção jurídica que, sem a posse, não possui valor e não é protegida pelo direito agrário. A posse é situção de fato, de existência histórica e anterior à propriedade, podendo ser objeto de compra e venda e, dada a importância do correto uso dos bens, especialmente a posse sobre área rural.

Em se tratando de área rural ou de imóvel rural, é inconcebível, diante das atuais exigências constitucionais, o que estabelece o Código Civil, dizendo, que o proprietário tem a

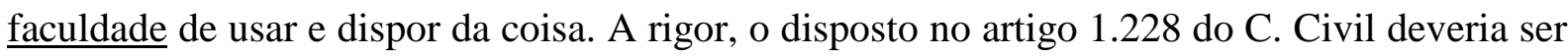
identificado como inconstitucional, não fosse sua aplicação genérica também a imóveis urbanos. Os dispositivos legais do código civil que regulam a posse os direitos do possuidor são mais propriamente aplicáveis no meio urbano. Trata-se de uma posse mais estática, que não precisa estar vinculada ao trabalho diário de produção dentro das condições de cumprimento da função social da terra.

A posse civil, tal como prevista no Código Civil não estabelece maiores exigências ao possuidor em relação ao cultivo da terra. Não há sequer exigência do possuidor residir no imóvel, urbano ou rural, e nem mesmo que o possuidor explore alguma atividade econômica específica. Assim, a posse poderia ficar caracterizada por meros atos de conservação e pagamento de tributos, mesmo que a finalidade fosse claramente especulativa. 
A legislação civil é razoável para a regulamentação da posse sobre os bens em geral, inclusive os imóveis urbanos. Ainda assim, em se tratando de imóvel urbano, há a exigência constitucional de que também cumpra a sua função social e natural, no caso, devendo destinar-se à habitação. Aliás, a finalidade social está fixada para todo e qualquer empreendimento econômico, como se prevê no princípio geral da ordem econômica (Art. 170 da CF).

O uso da terra enquanto possuidor, como prevê o Código Civil, vinculando-o com o direito do proprietário, aparece como uma faculdade. Em se tratando de área rural, a faculdade de usar a terra contradiz frontalmente as exigências da Constituição Federal e da legislação específica, no sentido do uso da terra de tal forma que cumpra as exigências da função social, no interesse da coletividade. As exigências constitucionais deixam claro que não há faculdade de uso, e sim obrigação de uso adequado da terra, independente da condição de titular, seja proprietário e, por consequência, possuidor, ou meramente possuidor.

No caso de posse de área rural, independente da condição do possuidor, proprietário ou não, a posse agrária é o exercício diuturno da atividade agrária, de tal forma que a terra cumpra a sua finalidade social, atendendo às exigências previstas na Constituição Federal (art. 186). É esta a posse que efetivamente leva à usucapião agrária, além de outras repercussões legalmente previstas.

Dos aspectos apontados acima evidencia-se que o nosso ordenamento jurídico, com os novos dispositivos constitucionais, dá mais ênfase e proteção à correta utilização da terra do que ao domínio dela. Em outras palavras, para o direito agrário a posse é mais importante, sob o ponto de vista da proteção jurídica, do que o domínio (a propriedade).

A posse agrária tem fundamentos distintos da posse civil. A posse agrária merece ser protegida em razão da posse mesma e não apenas em função da propriedade. Aliás, a posse agrária merece proteção mesmo contra a propriedade, quando seu titular não dá à terra o correto uso. Nesta visão, o fundamental é a atividade agrária, sobretudo aquela que é desenvolvida dentro dos padrões que atendam aos requisitos da função social da terra. Neste sentido, as disposições do Código Civil devem ser interpretadas à luz da Constituição Federal, levando em conta que, tratando-se de imóvel rural, há princípios próprios que devem ser observados. 


\section{MILTON INÁCIO HEINEN}

Pela melhor interpretação, fica (ou deveria ficar) sem proteção possessória a propriedade imóvel rural que não cumpre com sua função social. A CF demonstra que o não cumprimento da função social está diretamente ligado à perda da propriedade, de forma indenizada. Este é o verdadeiro sentido e alcance da função social da propriedade imobiliária rural. Em outras palavras, a Constituição Federal estabelece ao proprietário, como condição para a garantia de tal direito, o adequado uso da terra, mediante atos de produção e preservação, visando o interesse da coletividade. Portanto, os atos efetivos de posse é que garantem o direito e não a titularidade, o que está a demostrar a superioridade da posse, em termos de importância social, em relação à propriedade. É dentro destas exigências que se extrai o conceito de posse agrária. Portanto, as exigências impostas ao proprietário também devem ser verificadas em face do possuidor que pretende ver reconhecida a propriedade.

Há julgados dos nossos tribunais que estão em consonância com este entendimento, como o que segue:

O direito privado de propriedade, seguindo-se a dogmática tradicional (Cód. Civil, arts. 524 e 527), à luz da Constituição Federal (art. $\left.5^{\circ}, 11\right)$, dentro das modernas relações jurídicas, políticas, sociais e econômicas, com limitações de uso e gozo, deve ser reconhecido com sujeição à disciplina e exigência da sua função social. (arts. 170,II e III, 182, 183, 185 e 186, CF). ${ }^{4}$

Getúlio Targino Lima, em sua obra "A posse agrária sobre bem imóvel”, a conceitua como sendo

o exercício direto, contínuo, racional e pacífico, pelo possuidor, de atividades agrárias desempenhadas sobre os bens agrários que integram a exploração rural a que se dedique, gerando a seu favor um direito de natureza real especial, de variadas conseqüências jurídicas, e visando ao atendimento de suas necessidades e da humanidade. ${ }^{5}$

A posse agrária pode trazer como consequiências o direito de defesa e manutenção na posse, a legitimação e regularização da mesma, a aquisição da área possuída pela usucapião e, em caso de desocupação da área, a indenização e a retenção por benfeitorias.

Como visto acima, posse agrária traz maiores exigências do que a posse civil. Começa por exigir sujeito capaz (pessoa física ou jurídica), que efetivamente tenha condições de desenvolver a atividade agrária, que se manifesta sob diversas formas, principalmente a de produção. Quanto à posse civil, esta é inclusive reconhecida para o incapaz e, neste caso, 
exercida através de terceiros.

A posse agrária é identificada a partir da exploração de atividade tipicamente agrária, de forma racional e adequada, com respeito ao meio ambiente e às normas que regulam as relações de trabalho. Assim, a simples manutenção de uma ou algumas benfeitorias, numa forma estática, ou de atos meramente conservatórios da coisa, não chegam a caracterizar a atividade agrária e, muito menos, a posse agrária. Mais distante da caracterização da posse agrária fica a situação fática de manter a terra inerte, baseada apenas no domínio, numa espécie de intenção de possuir. É fato que boa parte do judiciário, ao apreciar os litígios possessórios, ainda fica preso a esta visão, onde a simples intenção do proprietário é suficiente para a comprovação da posse, o que, neste caso, é feito com a certidão da propriedade. Igualmente, não pode ser identificada a posse de área rural de dimensões quilométricas quando o proprietário se restringe a utilizar pequena parte com alguma atividade produtiva, deixando o restante inerte e sem qualquer utilização econômica e social.

O Código Civil ainda faz referência a várias modalidades de posse. Trata, por exemplo, da posse direta, que alguns chamam de derivada, como sendo aquela resultante de ajuste de vontades, por exemplo, de contrato de arrendamento ou de parceria. Neste caso, o proprietário manteria a posse indireta. De fato, o proprietário, nesta situação, não tem posse, vez que esta foi transferida mediante contrato. Contudo, esta posse direta, normalmente temporária, não gera os mesmos efeitos da aquisição da propriedade. Neste caso, os direitos resultantes da posse são outros, como o direito de retenção por benfeitorias e plantações e o direito de indenização por estas.

O Código também identifica a posse justa (que não é violenta, clandestina ou precária) e, de consequência, a posse injusta, além da posse de boa-fé (quando o possuidor ignora o vício, ou o obstáculo que impede a aquisição da coisa) e, por consequência, de má-fé (quando sabedor de obstáculo que impede a aquisição), e ainda, a posse com justo título ou sem justo título. São, na verdade, modalidades que, em se tratando de área rural, precisam ser interpretadas à luz das exigências constitucinais, em relação ao adequado uso da terra.

Não se pode entender como justa a posse cujo titular não exerce efetivamente a atividade agrária em consonância com as exigências constitucionais. Se não houver produção R. Fac. Dir. UFG, v. 38, n. 2, p. 80 - 96, jul. /dez. 2014 


\section{MILTON INÁCIO HEINEN}

sequer há posse. Nestas condições não há que se falar em esbulho possessório praticado por terceiro que se apossa por qualquer forma de imóvel alheio, ou parte específica deste, em que não há atividade agrária. Portanto, não caberia decisão, seja liminar ou de mérito, reintegrando na posse o proprietário que não realiza atividade agrária, vez que sequer possui ou possuia posse, não se caracterizando, então, o esbulho possessório, ou seja a perda da posse. Não se perde o que não se tem.

Na mesma linha de raciocínio, o critério identificador da boa ou má fé precisa ser revisto. $\mathrm{O}$ apossamento de área sabidamente pertencente a terceiro proprietário, quando esta não é utilizada por atividade agrária, não pode ser concebida como posse de má fé na medida que visa dar a esta terra a sua destinação social, quando isto é demonstrado por atos diuturnos de produção por parte de quem busca nesta terra a sua única alternativa de sobrevivência. Ao contrário, age de má fé o proprietário que mantêm inerte a sua propriedade, dando a ela um caráter meramente expeculativo, vez que, ciente das determinações constitucionais, não dá cumprimento a elas.

Mais importante do que fixar um rol de adjetivos qualificadores da posse, como se fez na lei civil, a posse agrária supõe o uso adequado da terra, vista como bem de produção de natureza especial, de tal modo que desempenhe efetivamente a sua função social. Nestas condições, a posse agrária tem presente os elementos da produção e produtividade (econômico), a conservação dos recursos naturais e preservação do ambiente (ecológico) e o cumprimento dos aspectos sociais relativos ao trabalho. Esta posse qualificada possui outra característica que a distingue da posse civil. Esta, como já dito, pode ser exercida por terceiros, ao passo que a posse agrária supõe a pessoalidade no exercício da atividade agrária.

Discute-se, no entanto, se resultaria descaracterizada a posse agrária no caso do desenvolvimento da atividade mediante a ajuda de terceiros, especificamente com o serviço auxiliar de empregados. O fundamental é identificar o correto uso da terra e o cumprimento dos elementos da função social. Neste sentido, aparece outro elemento que, para alguns

autores, como Hironaka ${ }^{6}$, é elemento característico e constitutivo da posse agrária, qual seja a moradia habitual na área possuída. Em se tratando de posse de pequena dimensão que, cumpridas as demais exigências, é capaz de levar à usucapião agrária, nos limites e condições previstas no artigo 191 da Constituição Federal, e de certo modo equivalente à usucapião especial prevista na Lei $n^{\circ}$ 6.969/81 (usucapião especial), verifica-se que a moradia habitual R. Fac. Dir. UFG, v. 38, n. 2, p. 80 - 96, jul. /dez. 2014 
de fato é condição necessária. Indaga-se, no entanto, se esta exigência é imposa a todo possuidor para que se identifique a posse agrária e, igualmente, se dela depende a possibilidade da usucapião, objeto de análise a seguir.

Pelas considerações aqui apresentadas, evidencia-se que as regras do Código Civil relativas à posse, e igualmente as refentes à propriedade, incluída a aquisição desta pela usucapião, devem ser interpretadas à luz das determinações constitucionais e não o contrário, como frequentemente ocorre na prática do judiciário. Por isso não cabe a proteção possessória a quem não cumpre a função social da terra na condição de proprietário de imóvel rural.

\section{Usucapião}

Tendo presente que a usucapião é a aquisição da propriedade, de forma originária, em decorrência da posse prolongada pelo tempo dentre as demais exigências legais, e levando em conta as diferenças verificadas entre a posse civil e a posse agrária, notadamente quanto aos requisitos para a sua identificação ou reconhecimento, cabe, igualmente, demonstrar o tratamento diferenciado a ser dado à aquisição da propriedade pela usucapião, com enfoque específico voltado para a posse ad usucapionem de área rural.

\subsection{Usucapião Civil e Usucapião Agrária - Caracterização e diferenças}

Não é qualquer posse que é capaz de gerar a usucapião agrária. Faz-se necessária a posse agrária que, como já dito, supõe a atividade agrária, dentro da finalidade social da terra.

O Código Civil estabelece exigências frágeis relacionadas com as consequências da posse, entre as quais a aquisição da propriedade pela usucapião. É a chamada usucapião civil. Adquirir uma certa área rural em razão do tempo de posse e demais exigências estabelecidas no Código Civil é muito fácil, mas não leva necessariamente a cumprir a função social da terra. Pelas condições exigidas no Código Civil, no extremo, alguem poderia adquirir a propriedade pela usucapião e, no dia seguinte, ter sua terra desapropriada por interesse social para fins de reforma agrária, por descumprimento dos requisitos da função social da terra.

Evidentemente não se está falando da usucapião prevista no artigo 191, caput, da R. Fac. Dir. UFG, v. 38, n. 2, p. 80 - 96, jul. /dez. 2014 


\section{MILTON INÁCIO HEINEN}

Constituição Federal, batizada de usucapião constitucional agrária, cujo teor foi repetido no artigo 1.239 do Código Civil. Esta modalidade de usucapião, também chamada de pro labore, que não difere da usucapião regulada pela Lei $n^{\circ}$ 6.969/81, exceto no limite máximo de área a ser usucapida, exige a moradia do possuidor, utilização da área pelo trabalho pessoal e o de sua família tornando-a produtiva, tendo ali a sua moradia, e que não seja proprietário de imovel urbano ou rural. Cumpre, portanto um papel fundamental de garantir acesso definitivo à terra, oportunidade de trabalho e renda e distribuição desta de forma mais equitativa.

Diante disso, pergunta-se: por que tanta exigência em comparação com a usucapião prevista no artigo 1.238 do Código Civil, onde apenas há fixação de tempo de posse maior?

Observe-se que a aquisição da propriedade pela usucapião, cumpridas as poucas exigências do C. Civil, não distingue área urbana da rural, como se as obrigações relativas ao correto uso fossem as mesmas. Além do mais, o citado dispositivo do Código Civil não faz qualquer referência a tamanho limite de área a ser usucapida, a posse direta e pessoal pelo possuidor ad usucapionem e nem mesmo a restrição de aquisição quando o possuidor já é proprietário de outros imóveis rurais e, por vezes, de grandes dimensões. Apenas fixa prazo mínimo de 15 anos, ou dez anos conforme o caso, de prova da posse.

A posse aqui tratada, além das facilidades já indicadas acima, não exige efetiva produção capaz de atender as exigências sociais e constitucionais. Como se verifica no Parágrafo Único do artigo 1.238 do Código Civil, se o possuidor tiver feito no imóvel sua moradia habitual, ou tiver realizado no imóvel obras ou serviços de caráter produtivo, tendo transcorrido o prazo de dez anos, adquirirá a propriedade pela usucapião.

Cabe observar que as exigências não são cumulativas. Assim, a aquisição pela usucapião pode decorrer tanto da moradia habitual como de alguma atividade produtiva, não se falando aqui do cumprimento pleno dos aspectos que compõem a função social da terra.

Voltemos ao que estabelece o caput do artigo 1.238, dizendo que "aquele que, por 15 anos, sem interrupção, nem oposição, possuir como seu um imóvel, adquirir-lhe-á a propriedade (...)". Como se verifica, aqui a regra não exige qualquer atividade de produção. Esta conclusão é reforçada pelo disposto no parágrafo único do referido dispositivo legal. Por R. Fac. Dir. UFG, v. 38, n. 2, p. 80 - 96, jul. /dez. 2014 
dedução lógica, se o fato da moradia, ou a realização de alguma atividade de caráter produtivo, reduz o prazo da usucapião para 10 (dez) anos, a de 15 (quinze) anos não exige nada disso, podendo então a chamada "posse" se restringir a meros atos de conservação e pagamento de tributos, por exemplo. Ora, nestas condições, a aquisição da propriedade pela usucapião é até aceitável em se tratando de imóvel urbano, mas jamais de área rural tendo por base apenas as exigêncais do Código Civil.

Como se vê, aqui a posse civil, capaz de gerar a aquisição da propriedade, também está diretamente vinculada à noção de propriedade, ou melhor, ao direito de propriedade, como bem patrimonial de uso pessoal, sem qualquer caráter social e não necessariamente ao efetivo uso produtivo da coisa. Não há, na legislação civil, exigência clara em relação à efetiva produção no sentido de atender aos interesses da coletividade.

O fato é que, levando em conta as exigências de cumprimento da função social da terra, independente da condição de proprietário ou possuidor com ânimus domini, esta modalidade não poderia ser aplicada no meio rural por conflitar com os princípios e exigências específicas do Direito Agrário e, mais ainda, com as exigências constitucionais de correto uso da terra.

\subsection{Requisitos da usucapião agrária}

A usucapião agrária possui fundamentos constitucionais, com outras e maiores exigências do que aquelas fixadas no Código Civil.

Como já afirmado anteriormente, a usucapião definida no artigo 191 da Constituição Federal ( redação repetida no art. 1.239 do Código Civil), exige que o possuidor seja pessoa física, não titular de outra propriedade, que desenvolva pessoal e diretamente a atividade agrária, com animus domini (possuir como sua), em área de no máximo 50 (cinquenta) hectares, por si e sua família, sem oposição nem interrupção e por um prazo mínimo de 5 (cinco) anos, tendo ali a sua moradia efetiva e tornando a área produtiva. Há autores que entendem não ser requisito essencial a realização apenas pessoal da atividade agrária, admitindo também a atividade feita por terceiros (contratados).

A usucapião agrária tem recebido várias denominações, entre as quais: usucapião R. Fac. Dir. UFG, v. 38, n. 2, p. 80 - 96, jul. /dez. 2014 


\section{MILTON INÁCIO HEINEN}

constitucional (porque prevista na CF), usucapião pro-labore ( porque fundada principalmente no trabalho), usucapião especial (conforme denominação feita na Lei 6.969/81), e a própria usucapião agrária ( pelo fato de esta expressão levar mais coerência com o verdadeiro sentido da aquisição da propriedade rural, mediante uma atividade agrária diuturnamente exercida sobre a terra.

Mesmo existindo os dispositivos constitucionais, ainda assim, levando em conta o âmbito agrário, como conteúdo ou instituto do Direito Agrário, a melhor denominação é de usucapião agrária.

A denominação de usucapião pro labore foi inserida pela primeira vez na Constituição Federal de 1934, para posse comprovada de pelo menos 10 anos, em área de até 10 hectares. A CF de 1946 elevou a área para 25 hectares. O Estatuto da Terra, mantendo o prazo, garantiu o direito de usucapir área de um módulo rural. Com a Lei ${ }^{\circ}$ 6.969/81, recebeu o nome de usucapião especial, de área de até 25 hectares e reduzindo o prazo para 5 anos.

Cabe observar que a usucapião especial (lei 6.969/81), a partir do estabelecido no artigo 191 da Constituição Federal, sofreu alterações, notadamente no tocante à área usucapível, aumentada de 25 (vinte e cinco) para 50 (cinquenta) hectares, sendo que de resto dita lei continua com perfeita aplicação, menos em relação aos imóveis públicos que não são mais usucapíveis, conforme parágrafo único do art. 191 da Constituição Federal. A dúvida doutrinária fica por conta do alcance da expressão imóveis públicos, entendendo alguns que as terras devolutas ainda poderiam ser objeto de usucapião mesmo após o advento da CF/88.

A usucapião em terras devolutas é entendida como cabível por parte da doutrina agrarista, apesar de divergências a respeito, levando em conta a redação do dispositivo constitucional do artigo 191 e a própria conceituação de imóvel rural. É que o conceito de imóvel rural supõe uma área de terra perfeitamente identificada, com seus limites e confrontações, o que não ocorre com as terras devolutas, uma vez que ainda se faz necessária a sua identificação, delimitação, demarcação, arrecadação e registro. Após este procedimento podem ser denominados de imóveis, como espécie de terras públicas ou bens públicos que o constituinte excluiu da aquisição por usucapião. Nestas condições, há teses doutrinárias a defender a possibilidade de aquisição, pela usucapião, de terras devolutas, por não se enquadrarem perfeitamente no conceito de imóvel rural. 
O judiciário, por sua vez, não tem enfrentado devidamente esta questão, limitando-se a repetir que não cabe usucapião de imóveis públicos.

De qualquer forma, a usucapião agrária supõe a posse agrária e esta deve ser a única forma de aquisição da propriedade imóvel rural em decorrência da posse prolongada no tempo e com o exercício da atividade agrária dentro das demais exigências consitucionais.

É razoável concluir que o possuidor não tem condições de comprovar, desde o primeiro dia de sua posse, que cumpre fielmente os elementos constitutivos da função social da terra. No entanto, estas condições precisam ser comprovadas por ocasião do requerimento em juizo da declaração da propriedade por sentença, ou no decorrer da instrução processual. Caso contrário, haveria tratamento estranho e desigual em relação ao reconhecimento do direito pleno de propriedade. Ora, como entender aplicável à propriedade imóvel rural um conjunto de exigências de adequada utilização e exploração, no interesse da coletividade, como condição para a garantia do direito de propriedade, e não estabelecer a mesma exigência ao possuidor quando este pretende que lhe seja reconhecida e declarada a propriedade.

Do exposto acima, é de se concluir que o Código Civil, com suas poucas exigências, não pode ser utilizado para a aquisição de área rural pela usucapião, exceto a situação prevista no art. 1.239. Os dispositivos do Código Civil relacionados com a posse não levam ao cumprimento da função social da terra. É de se entender que o possuidor, ao adquirir a propriedade de área rural pela usucapião, também precisa cumprir todos os aspectos da função social da terra. Neste sentido, precisa ficar claro que a exigência da função social não pode ser vista apenas como obrigação do proprietário, razão porque é mais adequada a expressão função social da terra, independente da condição do titular, se proprietário ou apenas possuidor.

De qualquer forma, cabe reconhecer que existem duas modalidades de usucapião a incidir sobre área rural, quais sejam, a usucapião agrária constitucional, prevista no artigo 191 e repetida no artigo 1.239 do Código Civil, com exigências próprias como limite máximo de área, entre outras e, em contrapartida, prazo de posse reduzido para a aquisição da propriedade, e a usucapião de área maior, sem limite de tamanho, sem a necessária moradia na posse, com a atividade agrária desenvolvida não apenas e necessariamente pelo trabalho R. Fac. Dir. UFG, v. 38, n. 2, p. 80 - 96, jul. /dez. 2014 


\section{MILTON INÁCIO HEINEN}

familiar, podendo contar com a ajuda de terceiros, para a qual está fixado o prazo mínimo de posse de 15 ou 10 anos.

É esta modalidade de usucapião que, como já dito, não pode ficar restrita às parcas exigências do Código Civil. Cumprido o tempo mínimo legal, a posse deve igualmente ser qualificada, no sentido de resultarem demonstras as condições de uso/exproração, mediante a realização de atividade agrária diuturna, a identificar o cumprimento da função social da terra.

Qualquer modalidade de usucapião a incidir sobre área rural deve supor o exercício da atividade rural com a participação direta e diuturna de quem se identifica como possuidor, ainda que conte com a ajuda de terceiros e mesmo que não tenha naquela terra a sua moradia habitual, o que é exigido para a usucapião de 5 (cinco) anos.

O animus domini em qualquer hipótese, e independente de documento, fica evidenciado pela prática da atividade agrária como se proprietário fosse, independente de reconhecer ou não que a titularidade do imóvel pertence a terceiro.

De qualquer forma, o aspecto essencial a reconhecer a titularidade da terra, estaria relacionado ao correto uso, com atividade agrária diuturna desenvolvida pelo possuidor, de modo a atender aos ditames constitucionais relativos à função social.

\section{Conclusão}

Como evidenciado, a posse e a propriedade urbana e rural possuem, e assim deve ser, critérios distintos de identificação, sendo a posse agrária mais dinâmica e com exigências maiores do que a posse urbana. Da mesma forma, e em decorrência disso, a propriedade agrária, ou propriedade imóvel rural, se submete a exigências outras e maiores do que aquelas estabelecidas para a propriedade imóvel urbana, como condição para a garantia e manutenção do direito de propriedade.

Por consequência, a aquisição da pripriedade imóvel rural pela usucapião também possui maiores exigências do que a aquisição da propriedade urbana em decorrência da posse. Nestas condições, o julgador, ao examinar o cumprimento dos requisitos para a declaração da aquisição da propriedade imóvel rural, não pode se limitar aos dispositivos do Código Civil, notadamente os artigos 1.238 e 1.243 , vez que estes devem ser aplicados com observância das R. Fac. Dir. UFG, v. 38, n. 2, p. 80 - 96, jul. /dez. 2014 
exigências constitucionais específicas estabelecidas para o correto uso da terra.

Neste sentido, reconhecendo a possibilidade de usucapião de áreas maiores do que o limite fixado no artigo 191 da Constituição, com o tempo de posse maior estabelecido nos dispositivos do Código Civil, devem ser demonstrados os demais elementos de efetivo comprimento da função social da terra, de forma a evitar tratamento diferenciado entre o proprietário e o possuidor que busca a declaração judicial da propriedade. Não pode alguém ser reconhecido como legítimo possuidor, e por consequência, não pode ser reconhecido como legítimo proprietário se não comprovar o cumprimento das exigências constitucionais que condicionam a garantia do direito de propriedade.

\section{Referências Bibliográficas}

ARAUJO, Fábio Caldas de. O usucapião no âmbito material e processual. Rio de Janeiro: Forense, 2003.

BARROS, Wellington Pacheco. Curso de Direito Agrário. Vol. 1 - Doutrina. Porto Alegre: Livraria do Advogado Editora, 2009.

BARROSO, Lucas Abreu e PASSOS, Cristina Lisita (Coord. e Co-autores). Direito Agrário Contemporâneo. Belo Horizonte: Del Rey Editora, 2004.

BRAGA, José dos Santos Pereira. Introdução ao Dir. Agrário. Belém: CEJUP/Fundação Lourenço, 1991.

LARANJEIRA, Raimundo (Coord). Direito Agrário Brasileiro. São Paulo: Ed. LTr, 1999.

LIMA, Getúlio Targino. A posse agrária sobre bem imóvel. São Paulo: Editora Saraiva, 1992.

MARQUES, Benedito Ferreira. Direito Agrário Brasileiro. São Paulo: Ed. Atlas, 2012.

\footnotetext{
${ }^{1}$ Hironaka, Giselda Maria Fernandes Novaes - Posse e propriedade. Apontamentos do Curso de Mestrado em Direito Agrário da UFG, 1996.

${ }^{2}$ Araujo, Fábio Caldas de - O usucapião no âmbito material e processual. Rio de Janeiro: Forense, 2003, p. 119 a 124. 1998, p. 19.

${ }^{3}$ Antônio Junqueira de Azevedo - entrevista publicada no Jornal Tribuna do Direito. Março de

${ }^{4}$ Acórdão Rip:20633, MS n. 1.835, Turma 1, Rel. Ministro Garcia Vieira, STJ Julg. Em 11/05/93.

${ }^{5}$ Lima, Getúlio Targino. A posse agrária sobre bem imóvel. S. Paulo: Ed. Saraiva, 1992, p. 84

${ }^{6}$ Hironaka, Giselda Maria Fernandes Novaes - Posse e propriedade. Apontamentos do Curso de Mestrado em Direito Agrário da UFG, 1996.
} 